\title{
Upaya Meningkatkan Jaminan Perlindungan Pekerja Migran Indonesia
}

\author{
Solechan, Tri Rahayu Utami, Muhamad Azhar \\ Fakultas Hukum Universitas Diponegoro \\ Jl. Prof. Soedarto, SH Tembalang Semarang \\ Email: tria2809@gmail.com
}

\begin{abstract}
Abstrak
Berdasarkan Pasal 1 Angka 3 Undang-Undang Nomor 18 Tahun 2017 tentang Perlindungan Pekerja Migran Indonesia, Pekerja Migran Indonesia adalah setiap warga negara Indonesia yang akan, sedang, atau telah melakukan pekerjaan dengan menerima upah di luar wilayah Republik Indonesia. Human Capital Index (HCI) menempatkan Indonesia berada pada peringkat ke-87 atau urutan ke-6 di Asia Tenggara sehingga berpengaruh terhadap kualitas Pekerja Migran Indonesia. HCI Indoneisa yang rendah tentu perlu ditingkatkan untuk meningkatkan pula daya saing dan kualitas Pekerja Migran Indonesia yang akan menunjang daya tawar Pekerja Migran Indonesia di tingkat global. Penelitian ini dilakukan untuk mengetahui urgensi diperlukannya Peningkatan Posisi Daya Tawar Sebagai Upaya Meningkatkan Jaminan Perlindungan Pekerja Migran Indonesia Oleh Pemerintah.
\end{abstract}

Kata Kunci: Pekerja Migran Indonesia, Daya Tawar, Kualitas.

\begin{abstract}
Based on Article 1 Number 3 of Law Number 18 Year 2017 concerning the Protection of Indonesian Migrant Workers, Indonesian Migrant Workers are any Indonesian citizens who will, are or have done work by receiving wages outside the territory of the Republic of Indonesia. The Human Capital Index (HCI) ranks Indonesia at 87th or 6th in Southeast Asia so that it affects the quality of Indonesian Migrant Workers. The low Indonesian HCI certainly needs to be improved to improve the competitiveness and quality of Indonesian Migrant Workers who will support the bargaining power of Indonesian Migrant Workers at the global level. This research was conducted to determine the urgency of the need to increase the bargaining power position as an effort to improve the guarantee of protection of Indonesian migrant workers by the government.
\end{abstract}

Keyword: Indonesian Migrant Workers, Bargaining Power, Quality.

\section{A. Pendahuluan}

Data Badan Pusat Statistik (BPS) melalui data Agustus 2018, merilis bahwa sebesar 60\% lebih angkatan kerja Indonesia berpendidikan di bawah SMP (Badan Pusat Statistik, 2018). Human Capital Index (HCI) dalam rilisnya yang diterbitkan oleh Bank Dunia pada Oktober 2018 juga menyebutkan menempatkan Indonesia dengan HCI sebesar 0,53 atau peringkat ke87 dari 157 negara. HCI Indonesia berada di bawah Malaysia dengan nilai 0,62; Filipina 0,55; 
Thailand 0,60; dan Vietnam 0,67. ${ }^{1}$ Hal tersebut tentu berpengaruh pada posisi tawar, tingkat kualitas angkatan kerja Indonesia, tingkat daya saing (competitiveness) pekerja Indonesia, dsb.

Berdasarkan Pasal 1 Angka 3 Undang-Undang Nomor 18 Tahun 2017 tentang Perlindungan Pekerja Migran Indonesia, Pekerja Migran Indonesia adalah setiap warga negara Indonesia yang akan, sedang, atau telah melakukan pekerjaan dengan menerima upah di luar wiiayah Republik Indonesia.

Adapun berdasarkan data Badan Nasional Penempatan dan Perlindungan Tenaga Kerja Indonesia (BPNP2TKI) ${ }^{2}$, terdapat kasus hukum yang menimpa pekerja migran Indonesia sepanjang 2016 berjumlah 4.761 kasus. Sementara di tahun 2017 sebanyak 4.349 kasus. Sedangkan di 2018 sebanyak 3.598 kasus. Dengan demikian, total yang ditangani BNP2TKI sebanyak 12.708 kasus. Adapun data kasus pada bulan April-Juni tahun 2019 memperlihatkan terdapat 1.903 kasus dalam kurun waktu tiga bulan saja. Lemahnya data tersebut menunjukkan bahwa setiap tahunnya terdapat peningkatan kasus hukum yang dialami oleh Pekerja Migran Indonesia yang dapat merupakan akibat dari rendahnya HCI Indonesia seperti yang telah diuraikan sebelumnya.

Berdasarkan paparan singkat di atas, maka sebenarnya terdapat urgensi dipelukannya upaya peningkatan posisi tawar, tingkat kualitas angkatan kerja serta daya saing Pekerja Migran Indonesia yang dilakukan oleh Pemerintah sebagai pemangku kebijakan. Hal tersebut penting dilakukan sebagai upaya Pemerintah untuk mewujudkan tujuan negara, yakni untuk melindungi segenap bangsa. Oleh sebab itu, dalam artikel ilmiah kali ini, akan dibahas mengenai "Peningkatan Posisi Daya Tawar Sebagai Upaya Meningkatkan Jaminan Perlindungan Pekerja Migran Indonesia Oleh Pemerintah” untuk mengemukakan seberapa penting hal tersebut perlu dilakukan.

Berdasarkan uraian tersebut maka pentingnya penelitian ini diantaranya: Untuk memahami apa yang dimaksud Pekerja Migran Indonesia. Untuk mengetahui bagaimana upaya peningkatan posisi daya tawar sebagai upaya meningkatkan jaminan perlindungan pekerja migran indonesia oleh pemerintah. Adapun rumusan masalah dalam penelitian ini adalah Apa yang dimaksud dengan Pekerja Migran Indonesia? Dan Bagaimana upaya peningkatan posisi

\footnotetext{
1 https://www.kemenkeu.go.id/publikasi/siaran-pers/siaran-pers-indonesia-sambut-positif-human-capital-indexbank-dunial.

2 BNP2TKI, Data Penempatan dan Perlindungan PMI Periode Juni 2019, Jakarta Selatan: Pusat Penelitian, Pengembangan dan Informasi, hlm. 31.
} 
daya tawar sebagai upaya meningkatkan jaminan perlindungan pekerja migran indonesia oleh pemerintah.

\section{B. Pembahasan}

\section{Pekerja Migran Indonesia}

Undang-Undang Dasar Negara Republik Indonesia Tahun 1945 (UUD NRI 1945) menjamin setiap warga negara Indonesia mempunyai hak dan kesempatan yang sama tanpa diskriminasi untuk memperoleh pekerjaan dan penghidupan yang layak. Salah satu upaya pemerintah Indonesia untuk memberikan perlindungan terbaik kepada calon pekerja migran (tenaga kerja Indonesia) melalui berbagai kebijakan dan program pengelolaan migrasi tenaga kerja yang bertujuan untuk mencapai migrasi yang aman dan adil.

Bekerja merupakan hak asasi manusia yang wajib dijunjung tinggi, dihormati, dan dijamin penegakkannya. Tujuan adanya Undang-Undang Nomor 18 Tahun 2017 tentang Perlindungan Pekerja Migran Indonesia adalah bahwa Pekerja Migran Indonesia harus dilindungi dari perdagangan manusia, harus dilindungi termasuk perbudakan dan kerja paksa, korban kekerasan, kesewenang-wenangan, kejahatan atas harkat dan martabat manusia, serta perlakuan lain yang melanggar Hak Asasi Manusia (HAM).

Adapun pelindungan Calon Pekerja Migran Indonesia dan Pekerja Migran Indonesia bertujuan untuk:

a. menjamin pemenuhan dan penegakan hak asasi manusia sebagai warga negara dan Pekerja Migran Indonesia; dan

b. menjamin pelindungan hukum, ekonomi, dan sosial Pekerja Migran Indonesia dan keluarganya.

Dalam corak pemerintahan yang berorientasi pada pertumbuhan ekonomi, cara pandang ekonomi bisnis lebih mendominasi kebijakan mengenai penempatan buruh migran ketimbang pendekatan pemenuhan hak asasi buruh migran. Kenyataan ini diperlihatkan dari ketersediaan data yang dimiliki oleh pemerintah Indonesia. Data yang selalu menjadi acuan adalah data tentang angka penempatan dan data tentang perolehan remitansi, namun pemerintah tak pernah bisa menjawab ketika ditanyakan mengenai data terpilah berdasar jenis kelamin dan juga data mengenai kematian buruh migran dan 
Administrative Law \& Governance Journal. Volume 2 Issue 1, March 2020| ISSN. 2621-2781 Online

penyebabnya,data tentang bentuk kekerasan yang dialami buruh migran Indonesia serta jumlah buruh migran yang mengalami berbagai bentuk pelanggaran hak-haknya. ${ }^{3}$

Berikut akan dipaparkan data berdasarkan Data Penempatan dan Perlindungan PMI oleh BNP2TKI ${ }^{4}$ :

PENEMPATAN PMI BERDASARKAN SEKTOR FORMAL INFORMAL PERIODE 2019 (APRIL s.d JUNI)
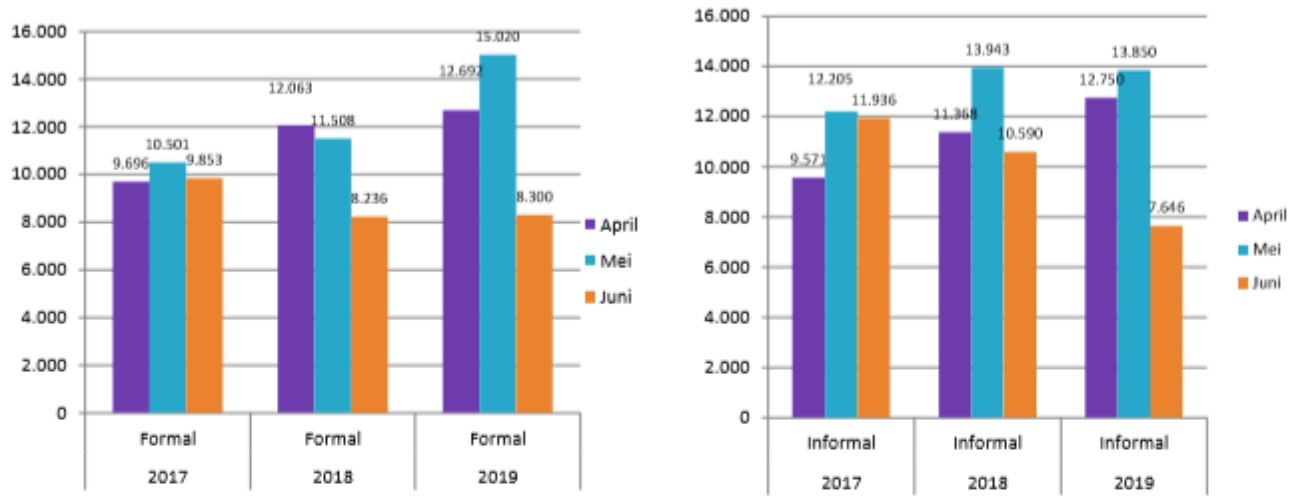

\begin{tabular}{|l|c|c|c|c|c|c|c|c|c|}
\hline \multirow{2}{*}{ BULAN } & \multicolumn{3}{|c|}{2017} & \multicolumn{3}{c|}{2018} & \multicolumn{3}{c|}{2019} \\
\cline { 2 - 12 } & Formal & Informal & Total & Formal & Informal & Total & Formal & Informal & Total \\
\hline April & 9.696 & 9.571 & 19.267 & 12.063 & 11.368 & 23.431 & 12.692 & 12.750 & 25.442 \\
\hline Mei & 10.501 & 12.205 & 22.706 & 11.508 & 13.943 & 25.451 & 15.020 & 13.850 & 28.870 \\
\hline Juni & 9.853 & 11.936 & 21.789 & 8.236 & 10.590 & 18.826 & 8.300 & 7.646 & 15.946 \\
\hline Total & 30.050 & 33.712 & 63.762 & 31.807 & 35.901 & 67.708 & 36.012 & 34.246 & 70.258 \\
\hline
\end{tabular}

Periode data di tarik pada tanggal 03 JUL 2019

\footnotetext{
${ }^{3}$ Wahyu Susilo, Pendidikan Sebagai Agenda Perlindungan Buruh Migran Indonesia, http://migrantcare.net/wpcontent/uploads/2016/09/artikel_JP_migran_dan_pendidikan.pdf,

${ }^{4}$ BNP2TKI, Loc. Cit.
} 


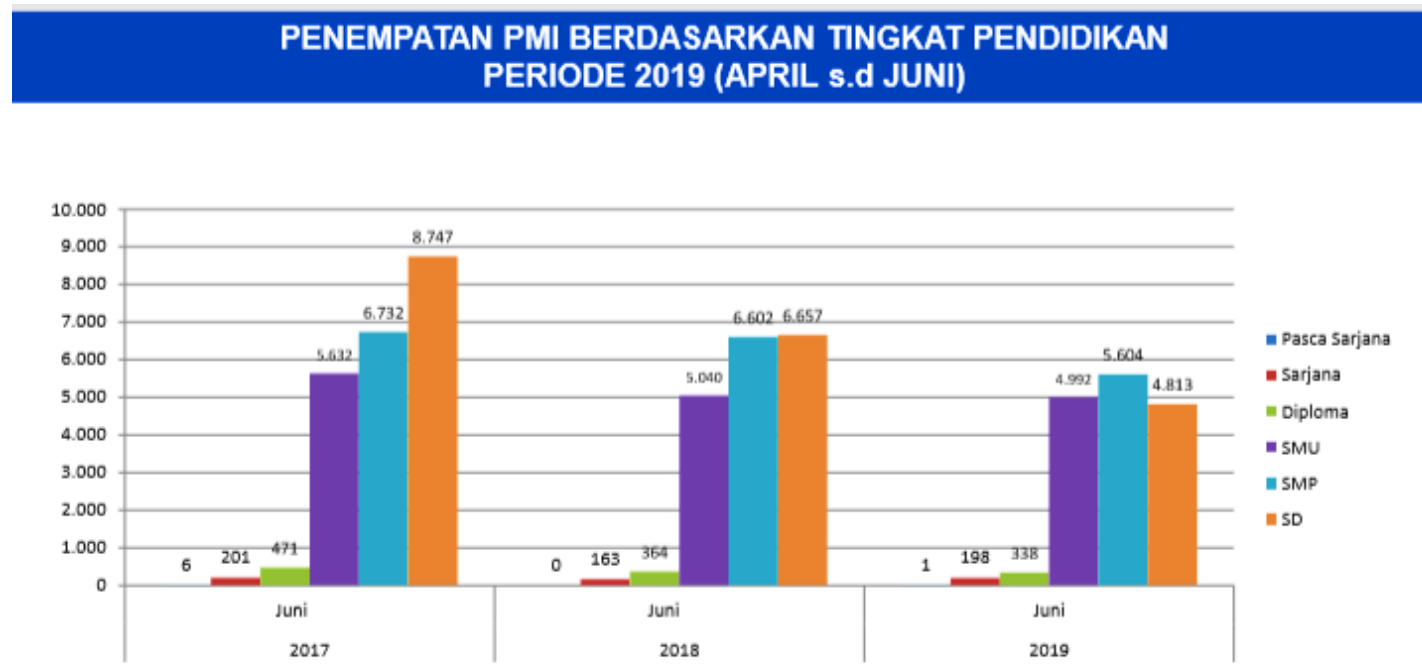

\begin{tabular}{|c|c|c|c|c|c|c|c|}
\hline \multirow{2}{*}{ NO } & \multirow{2}{*}{ TINGKAT PENDIDIKAN } & \multirow{2}{*}{$\begin{array}{c}2017 \\
\text { Juni }\end{array}$} & \multirow{2}{*}{$\begin{array}{c}2018 \\
\text { Juni }\end{array}$} & \multicolumn{4}{|c|}{2019} \\
\hline & & & & April & Mei & Juni & Total \\
\hline 1 & Pasca Sarjana & 6 & 0 & 3 & 3 & 1 & 7 \\
\hline 2 & Sarjana & 201 & 163 & 130 & 120 & 198 & 448 \\
\hline 3 & Diploma & 471 & 364 & 223 & 188 & 338 & 749 \\
\hline 4 & SMU & 5.632 & 5.040 & 8.027 & 8.758 & 4.992 & 21.777 \\
\hline 5 & SMP & 6.732 & 6.602 & 9.087 & 11.440 & 5.604 & 26.131 \\
\hline 6 & SD & 8.747 & 6.657 & 7.972 & 8.361 & 4.813 & 21.146 \\
\hline & Total & 21.789 & 18.826 & 25.442 & 28.870 & 15.946 & 70.258 \\
\hline
\end{tabular}

- Periode oata di terik pada tanggal 03 JUL 2019

Dari data tersebut dapat diketahui bahwa pada tahun 2017 terdapat sejumlah 33.712, tahun 2018 sejumlah 35.901, dan tahun 2019 sejumlah 34.246 Pekerja Migran Indonesia yang berada pada kluster informal dimana jumlah di tahun 2017 dan 2018 sektor informal memiliki angka total yang lebih tinggi daripada sektor formal. Sedangkan data lainnya menyebutkan bahwa sampai tahun 2019, Pekerja Migran Indonesia yang berjenis kelamin Perempuan menempati posisi $70 \%$ dari seluruh Pekerja Migran Indonesia. Adapun data terakhir mengenai tingkat pendidikan Pekerja Migran Indonesia dapat diketahui bahwa dari total 70.258 Pekerja Migran Indonesia, terdapat lebih banyak Pekerja Migran Indonesia yakni sejumlah 47.389 yang memiliki pendidikan di bawah Sekolah Menengah Atas (SMA). Sehingga dapat diketahui betapa pentingnya upaya pemerintah dalam peningkatan posisi tawar, tingkat kualitas angkatan kerja Indonesia, dan tingkat daya saing (competitiveness) terhadap Pekerja Migran Indonesia. 


\section{Upaya Peningkatan Posisi Daya Tawar Sebagai Upaya Meningkatkan Jaminan Perlindungan Pekerja Migran Indonesia oleh Pemerintah}

Menurut Harold J. Laski, tujuan negara adalah menciptakan keadaan dimana rakyatnya dapat mencapai terkabulnya keinginan-keinginan secara maksimal (creation of those conditions under which the members of the state may attain the maximum satisfaction of their desires). ${ }^{5}$ Salah satu agenda Pembangunan Nasional dalam Peraturan Presiden Republik IndonesiaNomor 2 Tahun 2015 tentang Rencana Pembangunan Jangka Menengah Nasional (RPJMN) 2015-2019 yaitu menghadirkan kembali negara untuk melindungi segenap bangsa dan memberikan rasa aman pada seluruh warga dengan menekankan kepada perlindungan hak dan keselamatan pekerja migran dengan sasaran utama yang ingin dicapai adalah menurunnya jumlah pekerja migran yang menghadapi masalah hukum di dalam dan luar negeri. ${ }^{6}$

Peran pelindungan pekerja Migran Indonesia diserahkan kepada pemerintah baik pusat maupun daerah, dimulai dari sebelum bekerja, selama bekeda, dan setelah bekerja. Pihak swasta hanya diberi peran sebagai pelaksana penempatan Pekerja Migran Indonesia. Dalam pelaksanaan Pelindungan Pekerja Migran Indonesia dibutuhkan pengawasan dan penegakan hukum yang tegas. Pengawasan mencakup pelindungan sebelum bekerja, selama bekerja, dan setelah bekerja. Penegakan hukum meliputi sanksi administratif dan sanksi pidana. Hal tersebut telah termaktub dalam penjelasan Undang-Undang Nomor 18 Tahun 2017 tentang Perlindungan Pekerja Migran Indonesia.

Adapun hal lain yang perlu diperhatikan adalah mengenai peningkatan posisi daya tawar yang perlu ditingkatkan oleh Pemerintah selaku pemangku kebijakan dikarenakan dapat meningkatkan jaminan perlindungan Pekerja Migran Indonesia. Ketentuan yang mengatur pendidikan sekurang-kurangnya lulusan SLTP atau sederajat diganti dengan SD. Berdasarkan kajian BPHN, fakta menunjukkan bahwa sebagian besar pencari kerja di Nusa Tenggara Timur (NTT) misalnya dan bahkan mungkin di Indonesia berpendidikan SD. Dalam putusan Mahkamah Konstitusi Nomor 019-020/PUUIII/2005 telah menganulir syarat pendidikan SLTP menjadi SD tetapi tidak semua Dinas Ketenagakerjaan

\footnotetext{
${ }^{5}$ Huala Adolf, Aspek-Aspek Negara Dalam Hukum Internasional, Bandung: Keni Media, 2011, hlm.45.

6 Badan Pembangunan Hukum Nasional, Laporan Akhir Analisis Evaluasi Mengenai Perlindungan Hak dan Keselamatan Pekerja Migran, Pusat Analisis dan Evaluasi Hukum Nasional BPHN: Jakarta, hlm. 2.
} 
kabupaten/kota NTT mengetahui hal itu, sehingga sampai dengan saat ini masih Dinas Ketenagakerjaan kabupaten/kota yang tetap berpedoman pada apa yang tertulis dalam Undang-Undang Nomor 39 Tahun 2004 tentang Penempatan dan Perlindungan Tenaga Kerja Indonesia di Luar Negeri yaitu pendidikan minimal lulusan SLTP karena mereka takut dijadikan tersangka oleh aparat kepolisian. Selain itu, mengganggap perlu disesuaikan dengan batasan jenjang pendidikan formal dengan materi revisi TKI menyertakan pendidikan terakhir minimal SD berijazah. Di provinsi Bali, TKI yang dikirim ke luar negeri ratarata berusia 21 sampai dengan 35 tahun, dengan latar belakang pendidikan minimal SMU/SMK, dan diperlukan batasan usia dan latar belakang pendidikan.

Kenyataan empirik menjadi sebuah fakta yang tidak terbantahkan, bahwa fenomena pekerja migran adalah sebuah gambaran dari kondisi buruknya tingkat hidup dan penghidupan masyarakat Indonesia dari sudut perekonomian, karena hampir 95\% dari pekerja migran adalah yang kondisi perekonomiannya bagian dari $80 \%$ masyarakat Indonesia yang tidak menjadi skala prioritas kebijakan ekonomi pembangunan. Dan selebihnya dikarenakan rendahnya tingkat pendidikan yang dimiliki, jumlah penduduk yang sangat tinggi yang menyebabkan ketidakseimbangan antara angkatan kerja dengan lapangan kerja yang tersedia. ${ }^{7}$ Pasar kerja merupakan arena dimana terdapat rangkaian antara penawaran dan permintaan dan sangat dipengaruhi oleh ketersediaan tenaga kerja (man power) yang dalam istilah ekonomi disebut sebagai tingkat penawaran dan permintaan tenaga kerja. Banyaknya tingkat penawaran yang tidak diimbangi oleh meningkatnya permintaan tenaga kerja menyebabkan terjadinya pengangguran. ${ }^{8}$

Secara kualifikasi, TKI yang dikirim dan bekerja sebagai pekerja migran, dikelompokkan menjadi 3 (tiga) golongan, yaitu: non skilled labour, semi skill labour dan full skill labour. Adapun jumlah terbesar yang dikirim adalah yang non skilled labour dan bekerja pada sektor informal di rumah tangga. ${ }^{9}$ Daya tawar yang rendah bagi pekerja migran biasanya disebabkan oleh kurangnya pengetahuan, pendidikan, keahlian, dan terutama kemampuan berkomunikasi dengan baik. Beberapa bentuk implikasi dan keresahan sosial yang timbul di tengah masyarakat terhadap pekerja migran.

\footnotetext{
${ }^{7}$ Fathor Rahman, Menghakimi TKI mengurai Benang Kusut Perlindungan TKI, Jakarta: Pensil-324, 2011, hlm.4.

${ }^{8}$ Ayumidah, Blantika Hukum Ketenagakerjaan, Jakarta: PT. Sofmedia, 2011, hlm. 38.

${ }^{9}$ Erman Supomo, National Man Power Strategy, Jakarta: Kompas Gramedia, 2009, hlm. 104.
} 
Oleh karena itu, perlunya meningkatkan skill Pekerja Migran Indoensia khususnya pada tahap pendidikan dan pelatihan dimana calon pekerja migran umumnya diberikan pelatihan pendidikan sesuai dengan bidang pekerjaan yang akan dijalani. Selain mereka diberikan ketrampilan untuk memotivasi diri sendiri dalam rangka menjaga etos kerja yang baik. Kemudian para calon pekerja migran tersebut diwajibkan mengikuti ujian kompetensi di Balai Latihan Kerja Luar Negeri (BLKLN) yang telah mempunyai sertifikasi dari Kementrian Tenaga Kerja dan Transmigrasi.

\section{Simpulan}

Salah satu upaya pemerintah Indonesia untuk memberikan perlindungan terbaik kepada calon pekerja migran (tenaga kerja Indonesia) melalui berbagai kebijakan dan program pengelolaan migrasi tenaga kerja yang bertujuan untuk mencapai migrasi yang aman dan adil. Adapun hal yang perlu diperhatikan adalah mengenai peningkatan posisi daya tawar yang perlu ditingkatkan oleh Pemerintah selaku pemangku kebijakan dikarenakan dapat meningkatkan jaminan perlindungan Pekerja Migran Indonesia.

Pekerja Migran Indonesia yakni sejumlah 47.389 yang memiliki pendidikan di bawah Sekolah Menengah Atas (SMA). Sehingga dapat diketahui betapa pentingnya upaya pemerintah dalam peningkatan posisi tawar, tingkat kualitas angkatan kerja Indonesia, dan tingkat daya saing (competitiveness) terhadap Pekerja Migran Indonesia. Oleh karena itu, penting bagi pemerintah untuk meningkatkan skill Pekerja Migran Indoensia khususnya pada tahap pendidikan dan pelatihan dimana calon pekerja migran umumnya diberikan pelatihan pendidikan sesuai dengan bidang pekerjaan yang akan dijalani.

\section{Daftar Pustaka}

Ayumidah. Blantika Hukum Ketenagakerjaan. Jakarta: PT. Sofmedia. 2011.

Adolf, Huala. Aspek-Aspek Negara Dalam Hukum Internasional. Bandung: Keni Media. 2011.

Rahman, Fathor. Menghakimi TKI mengurai Benang Kusut Perlindungan TKI. Jakarta: Pensil-324. 2011.

Supomo, Erman. National Man Power Strategy. Jakarta: Kompas Gramedia. 2009. 
Administrative Law \& Governance Journal. Volume 2 Issue 1, March 2020| ISSN. 2621-2781 Online

Badan Pembangunan Hukum Nasional. Laporan Akhir Analisis Evaluasi Mengenai Perlindungan Hak dan Keselamatan Pekerja Migran. Jakarta: Pusat Analisis dan Evaluasi Hukum Nasional BPHN.

BNP2TKI. Data Penempatan dan Perlindungan PMI Periode Juni 2019. Jakarta Selatan: Pusat Penelitian, Pengembangan dan Informasi.

Wahyu Susilo, Pendidikan Sebagai Agenda Perlindungan Buruh Migran Indonesia, http://migrantcare.net/wp-

content/uploads/2016/09/artikel_JP_migran_dan_pendidikan.pdf

https://www.kemenkeu.go.id/publikasi/siaran-pers/siaran-pers-indonesia-sambut-positif$\underline{\text { human-capital-index-bank-dunia/ }}$ 